\title{
Mature Librarians and the University Faculty: Factors Contributing to Librarians' Acceptance as Colleagues
}

\section{Jean A. Major}

\begin{abstract}
In an exploratory study, eighteen mature librarians who are considered colleagues of teaching faculty were interviewed to understand actual instances of acceptance within an institution. Participants demonstrated that performing the role of librarian and exploiting campus governance activities contributed significantly to collegial acceptance and were used to advantage more often than a common interest in research. The most important factor, however, was self-confidence as a librarian. Models and mentors reportedly helped subjects learn to be colleagues with other faculty; library school often did not.
\end{abstract}

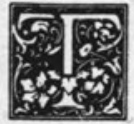

he Professional Liaison Committee of the Association of College and Research Libraries (ACRL) has focused, until now, only on other scholarly and professional associations and on techniques by which librarians might become more visible participants in them. In 1991, however, the ACRL Executive Committee approved an addition to the charge which gave a second focus to the committee:

.... In addition, the committee will seek to identify and promote strong relationships between libraries and institutional administrative, research and instructional units....

The committee interpreted this addition to its charge as a call for further exploration of the status, the respect, and the recognition which libraries, librarians, and library directors enjoy on local campuses. In early committee discussion about the charge, a suggestion was made that some mature librarians are able to function as colleagues of other faculty in situations where high regard for librarians is present. This paper is an exploration of that premise.

The voluminous literature concerning the status of academic librarians has focused mainly on questions of formal admission to the faculty. The association's official statements, represented now by the revised "Standards for Faculty Status for College and University Librarians" (1992), state the justification for faculty status and specify the privileges to which faculty librarians must have access. ${ }^{2}$ In addition to thorough explorations of librarians' admission to faculty status itself, criteria for tenure and promotion are often debated. Discussions of techniques for overcoming logistical problems, such as scheduling time for research, are prominent as well. ${ }^{3} \mathrm{~A}$ recent exploration of library faculty credibility, by W. Bede Mitchell and Bruce Morton, seems to turn from questions of simple admission to the faculty to a more ambitious level of academic citizenship. In this synthesis and interpretation of

Jean A. Major is University Librarian at Old Dominion University, Norfolk, Virginia 23529-0256. 
existing research, the authors noted that the present socialization of academic librarians is inadequate to function in the research-centered environment of other faculty. After a detailed examination of the relevant shortcomings of librarians' graduate education, the article concluded with an extensive set of recommendations to foster an appreciation for research, and more important skills in performing research on the part of new librarians. ${ }^{4}$ Little exploration has been undertaken concerning experienced librarians exhibiting successful library faculty behavior that is defined more broadly than research activity. Therefore, the perspective of the mature librarian-a person generally described as a colleague of the teaching faculty-was considered to be a fertile area for investigation and, moreover, an important vehicle for the committee's work.

Relevant concepts considered for this investigation of successful library faculty behavior are professionalism, especially the client-professional relationship, and collegiality. Librarians of all types consistently have embraced professionalism as the appropriate framework for their work. This model is defined, in part, by the requirements of formal training and specified credentials, by the existence of a code of ethics, and by autonomy in performing work. However, its most significant emphasis is on the delivery of expert services for a client-in which decisions about a client are made by the professional. The professional-client relationship is an essential part of this framework.

Collegiality, by contrast, defines relationships and interactions among members of the academic community-a community in which research and scientific inquiry are central and peers are primary judges of work. Mutual respect for expertise in research and teaching, shared values, and a decision-making style based on participation and consensus define collegial relationships. The framework of collegiality contrasts markedly with the concept of the professional interacting with a client, which has received such extensive attention in the literature of librarianship.
Four surveys of faculty opinion about the role and status of librarians were carried out during the eighties, at Southeastern Louisiana University, Southern Illinois University at Carbondale, University of Manitoba, and Albion College. Each survey included a question similar to the following: "Do you view librarians as: academics equal with teaching faculty, professionals, semi- or paraprofessionals, clerks, or others?" The majority of respondents in all surveys regarded librarians as professionals, but not as academic or faculty equals. The respective responses expressed in percentages were "professional" $-60 \%$, $65 \%, 68 \%$, and $85 \%$, and "academic equals" $-38 \%, 28 \%, 29 \%$, and $15 \%$. $^{5}$ These consistent survey results contrast with the current aspirations of academic librarians to be regarded as colleagues, with all the mutual respect and shared values that collegiality implies. It is essential, then, to understand actual instances of acceptance of librarians as colleagues within the academic communities of their own institutions.

\section{METHOD}

An exploratory study was chosen to identify issues which deserve programmatic or further research activity by the committee or by ACRL. Acceptance as colleagues by other faculty was defined as the recognition of a partnership, a relationship of equal status - and, therefore, equal access to shared research, governance, or social experiences-with faculty outside the library. Using this definition, practicing university library administrators were contacted for names of librarians who are accepted as colleagues by faculty in their own universities-and therefore who would be suitable subjects to interview. Openended telephone interviews were conducted with eighteen mature librarians selected from these names to represent a variety of library service roles. Because of the exploratory nature of the study, sampling was not considered, and raw data were not analyzed statistically. Rather, themes for further consideration were identified. 
The mature librarians who participated in the study had significant professional experience. More than half (11) had been librarians for twenty or more years. They represented a variety of aspects of the profession-collection development, reference, cataloging, serials, for example-but eight (nearly half) were subject specialists, representing science and engineering, social sciences, fine arts and music, and education.

Subjects came almost entirely from publicly supported universities; the median institutional enrollment in fall 1990 was 20,023. Most libraries (14) are ARL libraries; the remainder are comprehensive universities with a number of doctoral programs. Almost half of the participants (8) have professorial rank. The rest have alternate ranks (Librarian II, Associate Librarian, and so forth), but the privileges and responsibilities of the alternate ranks vary.

Questions asked of interview subjects were:

1. What kinds of contacts do you have with faculty in general?

2. How did the campus service aspect get started?

3. Are there some faculty whom you consider colleagues?

4. What are those relationships like? In what sense are you colleagues?

5. Identify some characteristics which would describe the relationships.

6. Are shared values a part of this?

7. Is professional library service a part of developing collegial relationships? How?

8. How did you learn to be a faculty member, to form professional friendships with other faculty?

\section{FINDINGS}

\section{Are There Some Faculty}

\section{Whom You Consider Colleagues?}

Nearly half (8) of the participants of this study answered this question emphatically, "Yes! I consider them all colleagues." The others had a great many or a few faculty colleagues. Only one subject, one of the more junior participants, reported that she does not consider any faculty outside the library her colleagues. The following findings describe these relationships more fully.

\section{Contacts with Faculty}

Library service assignments provided opportunities for substantive long-time faculty contact for most study participants. The single most common element was collection development responsibility. Most participants, twelve of the eighteen, spoke of some degree of collection development work: long-time liaison with several departments, the serial review process, development of the general collection, or service as the chief collection development officer, as well as the collection development which accompanies the role of subject specialist. Half were involved with bibliographic instruction at some level, and nine had considerable contact associated with service desks. In addition, some subject specialists reported presentations to research seminars, consultations about research strategies for pursuing faculty or students' projects, or regular phone or in-person contacts with constituents. These reported contacts sometimes were highly systematic; one bibliographer indicated that he makes 100 phone contacts every three months to his constituents.

The majority of subjects in this study are well integrated into the governance structure of the university and serve on universitywide committees, the faculty senate, or senate committees. Typical committee assignments for these librarians concerned campuswide promotion and tenure review, sabbaticals, teaching excellence, military education, bookstore, and senate library committees. Represented, although less common, was service on college curriculum committees, the senate steering committee, or the university's academic planning committee. One subject had served recently as president of the university senate, and another was a recent member of the university's athletic council. Service as Senate president carried with it the opportunity to serve on search committees, first for the university's president and then for the provost. Only one other participant reported regular 
service on search committees for nonlibrary positions.

Faculty contacts related to research were less frequent and more varied than other kinds of contacts. Only seven subjects specifically reported that they talked with teaching faculty about their research; five also discussed their own (librarians') research with their faculty colleagues. Other reported research-related activities were: service on thesis, dissertation, or other doctoral committees ( 3 participants); attendance at campus seminars, lectures, and colloquia as often as possible ( 3 -all subject specialists); joint research projects (only 2 participants); participation in a campus research center, interacting with other participants and giving papers (2); and service as a peer reviewer for a campus grant program (a single participant).

\section{The Process}

Many participants credited faculty status with creating opportunities to develop collegial relationships through campus service. Some universities' long history of faculty status for librarians makes this easier. Campus service opportunities opened up for some librarians only when they received faculty status midway in their careers. Where representation from each academic unit is required, librarians' participation is guaranteed, and some respondents have made use of these opportunities. In addition, all faculty-including librarians-receive forms to volunteer for Senate committees in most universities; those who respond frequently are chosen.

For other universitywide committee assignments, the recommendation or nomination of the library's administration was reported to be necessary-and one subject indicates she makes a practice of asking her administration to nominate her for activities in which she wishes to participate. Others noted that a supportive director made a big difference in gaining access to campuswide service opportunities. Only one subject with high campus visibility reported that he did not get encouragement from the library's administration to become active.

"It just goes on and on. Once you get started, they think of you." This quote from a highly visible campus politician suggests two themes mentioned by several subjects-becoming known and developing a track record. This librarian chaired a committee during the first year of her service in the Senate. As chair of the bookstore committee, she presided effectively over "a major Senate battle" and thus became known and respected. Another subject, an immediate past president of the faculty Senate, built a record over time, beginning with the American Association of University Pro-

The majority of subjects in this study are well integrated into the governance structure of the university and serve on universitywide committees, the faculty senate, or senate committees.

fessors (AAUP) and then in the Senate. She put in a great deal of hard work, showing what she could do-and observed, "In the end, it's up to your own abilities and how you're able to make the time." A third participant spoke directly of using university committee assignments to gain respect. She notes that she is careful to contribute at least as much as other committee members. "I don't go to meetings and sit." Fewer subjects have enhanced their collegial relationships within the framework of performing research, but several undertook deliberate activities which achieved this result. One bibliographer became an active participant in a campus research institute, giving papers, attending seminars conducted by other participants, and developing relationships with other scholars in the institute. When he began to participate, a totally different relationship resulted. Another participant initiated a jointly authored book project with another faculty member; her coauthor is the first faculty member whose interactions with her have had a 
collegial tone. A librarian who earned a $\mathrm{Ph} . \mathrm{D}$. midcareer observed that she has been taken more seriously since she received the Ph.D.

Finally, a long history at an institution was credited by some subjects for their acceptance as colleagues. One observed that the relationships get better as she gets older, while several noted, "It's a matter of who they know." Another concluded, "Professional respect has built up over time; now we know each other."

\section{Attitude-The Basis for Acceptance}

Half of the subjects indicated that interests in students, teaching, and the learning environment were commonalities that enhanced the collegial atmosphere between librarians and other faculty. Several subject specialists spoke of shared experiences-going to the same meetings, knowing the same people, sharing the same "in" experiences-and placed a premium on this common ground. However, the two themes that elicited extended comment from participants are the mutual value placed on research and the confidence an individual librarian brings to the relationship.

Those subjects who hold Ph.D.s have certified research interests. As one observed, the faculty know he places a similar value on scholarship and notes that many librarians do not share this commitment to scholarship and ideas. Of the study participants who spoke of their own research interests, all hold doctorates. Others, however, referred to their interest in their faculty colleagues' research. Some talk to people about their research and what they are doing. Several subjects spoke of their high regard for what faculty are doing. Another expanded on this theme:

I have bought into the university and the pursuit of knowledge, so I am dealing as an equal. If you don't buy into that pursuit, you are an outsider. . . Some librarians fall into this trap.

It is notable that every interview subject in this study expressed confidence in his or her role, contributions, or acceptance by colleagues on the teaching faculty.
Many regard themselves as experts on information access and the information retrieval process and expect to command respect on that basis. One subject observed that "her faculty" realize that she can be an adjunct in their research; they recognize her expertise. Another commented: "If librarians have a healthy attitude toward themselves ... . what they're doing is important; it is part of the scholarly world."

\section{Several participants noted that librarians must participate in relationships with other faculty on an equal basis.}

A few respondents remarked about the timidity many librarians bring to their relationships with other faculty. It was observed, "Too many librarians are timid souls; they wring their hands and want people to recognize them." Another pointed to the "motivational or psychological issue"-the degree of comfort in making overtures to faculty-and noted that those librarians who can get over this have a reasonable chance to succeed at a collegial relationship.

Several participants noted that librarians must participate in relationships with other faculty on an equal basis. As one subject observed, "We are equal. They represent a discipline, and I represent a discipline-a mutual type of thing." Another remarked, "We don't act as peers-a big mistake. I have interacted as an equal from day one. Most librarians just don't have the confidence."

\section{Learning to Be a Faculty Member}

In response to the question, "How did you learn to be a faculty member?" five subjects indicated that they had been raised in a faculty family, and three were former teaching faculty members themselves. Those who were faculty children commented that the faculty role was comfortable and familiar, that they had always been comfortable in a faculty atmosphere-"I always knew," and "Is 
there any other life?" Moreover, they were never intimidated: "No one in the academic world scares me; there is no one to be in awe of," or, "Having been raised in it is a great leveler; it takes undue respect out of it."

For those not fortunate enough to have been raised in an academic family, a mentor or a model was considered to be significant. As one subject described it: "I had a great mentor, a model, who did everything to facilitate this role. She [the director] pushed, expected, and helped me to get on committees." Another worked under the direction of a department head who was convinced of the importance of contact with faculty; he modeled techniques for doing it, which was very useful. A third formed mentoring relationships with more senior librarians in her first library position. Finally, in the experience of some subjects, more recent library directors have mentored library faculty and, thus, were credited with fostering collegial relationships between teaching faculty and their colleagues in the library.

The only interview subjects whose library school experience seemed relevant to their learning to be library faculty members were those who held Ph.D.s before going to library school. Those librarians all reported noting the scholarly activity of their library school professors and learning something about scholarship from the experience. All other subjects reported that library school-unlike the academic preparation for faculty in other disciplines-was irrelevant.

\section{SUMMARY AND CONCLUSIONS}

The librarians interviewed for this study indicated that considerable common ground exists between librarians and their faculty colleagues. A significant number define these shared values in terms of teaching and the learning environment. "We are all interested in students," or "We share a concern about the total experience for the student," are representative comments. Others-nearly half-find common values in research and scholarship, whether by the shared experience of performing re- search or by showing a high regard for the work faculty researchers do. Most of these mature librarians have become well integrated into their university's governance structure, aided by the specified representation required by faculty status and the fact that they know a significant number of faculty throughout the university. Committee service not dictated by requirements that the library be represented was less frequent. In carrying out committee responsibilities, developing a reputation for effective performance is regarded as essential in fostering collegiality.

The only interview subjects whose library school experience seemed relevant to their learning to be library faculty members were those who held Ph.D.s before going to library school.

The presence of a supportive library administration, effective models, and colleagues who acted as mentors-all these factors were helpful to some librarians both for learning to be a faculty member and to gain access to opportunities for campus involvement. Self-confidence in the librarian role, knowing people and being known, and overcoming the timidity factor-all point to the importance of "assuming" an outgoing personality to earn acceptance as a colleague of other faculty.

The primary issue examined in studies of librarians' professionalism-authority as a librarian-did not enter into these librarians' quest for acceptance as faculty colleagues. In fact, when the interview subjects spoke of commanding respect, they clearly meant the mutual respect of collegiality, rather than the respect a client has for a professional.

\section{RECOMIMENDATIONS FOR FURTHER STUDY}

The participants of this study have demonstrated that performing the role of librarian can be used to establish collegial relationships with other faculty when a librarian brings a collegial atti- 
tude to the interaction. In addition, a significant number, by volunteering, have exploited campus governance opportunities fully for the same purpose. A wide variety of other activities that were utilized-service on dissertation committees, acting as peer reviewers, participating in research seminars, serving on nonlibrary search committees-suggests avenues for librarians to broaden their collegial relationships. The ACRL Professional Liaison Committee could perform a service by identifying and publicizing more vehicles that academic librarians have used to establish the desired collegial relationships.

An appreciation for the role of scholarship in the university and the development of personal research interests were underrepresented in the comments of these mature librarians, even though about half of the subjects identified scholarship as a shared value. Working with the ACRL Research Committee, the Professional Liaison Committee should develop techniques to foster appreciation of these related issues as a contribution to better collegial relations.

Modeling and mentoring activities were identified as positive factors in the development of mature librarians. Libraries in which mentoring is taken seriously should be identified and studied for elements that can be generalized.

Individual librarians operating within a university library demonstrably can gain acceptance of colleagues in other disciplines. The carryover to the library as a whole or to the entire group of librarians should be investigated.

\section{REFERENCES AND NOTES}

1. ALA Handbook of Organization 1991/1992 (Chicago: ALA, 1991), 47.

2. Association of College and Research Libraries, Academic Status Committee, "Standards for Faculty Status for College and University Librarians," College \& Research Libraries News 53 (May 1992): 317-18.

3. See Janet Krompart, "Researching Faculty Status: A Selective Annotated Bibliography," College \& Research Libraries 53 (Sept. 1992): 439-49.

4. W. Bede Mitchell and Bruce Morton, "On Becoming FacultyLibrarians: Acculturation Problems and Remedies," College \& Research Libraries 53 (Sept. 1992): 379-92.

5. Larry R. Oberg, Mary Kay Schleiter, and Michael Van Houten, "Faculty Perceptions of Librarians at Albion College: Status, Role, Contribution, and Contacts," College \& Research Libraries 50 (Mar. 1989): 223. 